\title{
Hip fracture outcomes in patients with Parkinson's disease
}

\author{
Authors: Radcliffe Lisk, Hazel Watters and Keefai Yeong
}

\section{Introduction}

Patients with chronic idiopathic Parkinson's disease (PD) are at a high risk for fractures, particularly of the hip, accounting for $4.3 \%$ of all emergency admissions for PD patients. The causes may be multifactorial, including poor balance and other forms of neurological dysfunction. Osteopenia and osteoporosis leading to decreased bone mass are common in these patients.

These patients tend to have a longer hospital stay and are unlikely to return home within 30 days. Multidisciplinary teams (MDT) managing these patients need to be more aware of their potential complications, so as to improve outcomes. The aim of this audit was to establish whether outcomes from hip fracture in people with PD can be improved with targeted interventions.

\section{Methods}

A PD sticker was created to highlight all PD patients on the board round. We devised a PD hip fracture checklist which ensured:

1 clinic letter printed on arrival

2 PD medications prescribed and given on time

3 daily lying and standing blood pressure (BP) measurement

4 strict bowel care with regular laxatives and suppositories.

PD medications were made available on the ward, with a poster reminder for nurses on the drug trolley and a poster reminder on the drug cupboard where the PD meds are kept. A section was added to the neck of femur (NOF) proforma to remind doctors to ensure that medications are given even if nil by mouth (NBM).

PD patients were prioritised by the therapists for early intervention, and regular educational sessions were provided for staff.

Results

See Table 1.

\begin{tabular}{|c|c|c|c|c|}
\hline & \multicolumn{2}{|c|}{$\begin{array}{l}\text { Pre-intervention } \\
\text { (12-14 Dec) }\end{array}$} & \multicolumn{2}{|c|}{$\begin{array}{l}\text { Post-intervention } \\
\text { (15-16 May) }\end{array}$} \\
\hline & $\begin{array}{l}\text { PD } \\
\text { patients }\end{array}$ & $\begin{array}{l}\text { All } \\
\text { patients }\end{array}$ & $\begin{array}{l}\text { PD } \\
\text { patients }\end{array}$ & $\begin{array}{l}\text { All } \\
\text { patients }\end{array}$ \\
\hline No of patients & 28 & 808 & 22 & 421 \\
\hline Age & 82 & 84 & 82 & 84 \\
\hline Female & $60 \%$ & $72.2 \%$ & $73.9 \%$ & $72.8 \%$ \\
\hline $\begin{array}{l}\text { Independently } \\
\text { mobile }\end{array}$ & $21.4 \%$ & $48.3 \%$ & $13.6 \%$ & $40.2 \%$ \\
\hline AMTS & 6.4 & 6.9 & 5.9 & 7.4 \\
\hline $\begin{array}{l}\text { Intracapsular } \\
\text { fracture }\end{array}$ & $69.1 \%$ & $56.2 \%$ & $69.6 \%$ & $59.4 \%$ \\
\hline $\begin{array}{l}\text { Theatre within } 36 \\
\text { hours }\end{array}$ & $89 \%$ & $82 \%$ & $95 \%$ & $83 \%$ \\
\hline $\begin{array}{l}\text { Length of stay } \\
\text { (days) }\end{array}$ & 26.1 & 21 & 15.0 & 15.2 \\
\hline $\begin{array}{l}\text { Home to home in } \\
30 \text { days }\end{array}$ & $28.5 \%$ & $58.1 \%$ & $40.9 \%$ & $59.6 \%$ \\
\hline Mortality & $7.7 \%$ & $5.5 \%$ & $0 \%$ & $4.0 \%$ \\
\hline
\end{tabular}

\section{Conclusions}

MDT targeted interventions improve outcomes for PD patients with hip fracture. Cost-effective interventions such as these are essential to reduce the burden of hospitalisation for patients, carers and healthcare systems.

\section{Conflict of interest statement}

None. 